1950). There are, however, references in the literature to functioning oxyphil tumours (Schachner et al., 1966). In the present series predominantly chief cell and oxyphilic types occurred with almost equal frequency, and in Case 4 the sections examined showed a totally oxyphilic tumour.

From our findings and study of the literature it is clear that the pathological findings in familial forms of hyperparathyroidism vary considerably. Primary chief cell hyperplasia, single and multiple adenomata of varying cell type, and the phenomenon of nodular hyperplasia all occur (Black and Utley, 1968; Graber and Jacobs, 1968). Furthermore, the different changes may occur as part of the same pathological process, as Black and Utley (1968) suggested, and it is difficult to describe any appearance as typical.

The risk of recurrence in familial hyperparathyroidism is not limited to cases showing primary chief cell hyperplasia. We suggest it may be related to the presence of multiple gland involvement occurring as part of the natural history of the disease. If this is so then the more radical surgical approach suggested for cases of primary chief cell hyperplasia (Cope et al., 1958) may well be the treatment of choice in all forms of hyperparathyroidism with a clear familial basis, when more than one gland is found to be involved at operation.
We should like to thank the Cancer Research Campaign for their generous support in this project, and Mr. A. C. Wise for technical help.

\section{References}

Black, B. K., and Ackerman, L. V. (1950), Cancer, 3, 415

Black, W. C., and Utley, J. R. (1968). American fournal of Clinical Pathology, 49,761 .

Cassidy, C. E., and Anderson, A. S. (1960). Metabolism, 9, 1152.

Castleman, B. (1952). Atlas of Tumor Pathology, Section 4, Fascicle 15 Washington, D.C., Armed Forces Institute of Pathology.

Cope, O., Keynes, W. M., Roth, S. I., and Castleman, B. (1958). Annals of Surgery, 148, 375.

Cutler, R. E., Reiss, E., and Ackerman, L. V. (1964). New England fournal of Medicine, 270,859 .

Frohner, R. N., and Wolgamot, J. C. (1954). Annals of Internal Medicine, 40, 765 .

Graber, A. L., and Jacobs, K. (1968). Fournal of the American Medical Association, 204, 542.

Johnson, G. J., Summerskill, W. H. J., Anderson, V. E., and Keating, F. R. (1967). New England fournal of Medicine, 277, 1379.

Kleinfeld, G. (1959). Cancer, 12, 902.

Peters, N., Chalmers, T. M., Rack, J. H., Truscott, B. McN., and Adams, P. H. (1966). Postgraduate Medical fournal, 42, 228.

Schachner, S. H., Riley, T. R., Old, J. W., Taft, D. A., and Hamwi, G. J. (1966). Archives of Internal Medicine, 117, 417.

Shallow, T. A., and Fry, K. E. (1948). Surgery, 24, 1020

Wermer, P. (1954). American fournal of Medicine, 16, 363.

Reprint requests should be sent to Dr. P. Marsden, 26 Colbourne Road, Hove, Sussex.

\title{
Rhesus Isoimmunization after Abortion
}

\section{SHEILAGH MURRAY S. L. BARRON}

British Medical fournal, 1971, 3, 90-92

\section{Summary}

Out of $177 \mathrm{Rh}(\mathrm{D})$-negative patients studied, 96 were successfully followed-up after spontaneous or therapeutic abortion. Rh antibodies were detected by the indirect Coombs test in two patients and by an enzyme technique only in a further seven, an overall incidence of $9.4 \%$.

The prophylactic use of anti-D immunoglobulin is now recommended for $R$ h-negative non-immunized patients undergoing abortion, but the dose could be less than $75 \mu \mathrm{g}$. The Kleihauer test was of no value in predicting the risk of isoimmunization.

\section{Introduction}

We reported (Murray et al., 1970) that a potentially immunizing transplacental haemorrhage of $0.1 \mathrm{ml}$ of fetal blood or more was found in $2.9 \%$ of women who had undergone abortion. In most cases the transplacental haemorrhage had been observed before operation, leaving only 2 out of $405(0.5 \%)$ where the operation itself could be implicated as the cause of bleeding. We suggested that any decision about the administration of anti-D immunoglobulin to $\mathrm{Rh}(\mathrm{D})$-negative patients after abortion should await factual evidence about the rate of immunization in such patients. As supplies of anti-D immunoglobulin

Regional Transfusion Centre, Newcastle upon Tyne NE4 6QB SHEILAGH MURRAY, M.D., F.R.C.PATH., Director

Princess Mary Maternity Hospital, Newcastle upon Tyne NE2 3BD

S. L. BARRON, F.R.C.S., F.R.C.o.G., Consultant Obstetrician and Gynaecologist increase, such evidence becomes urgently required. We therefore report a relatively small series of $177 \mathrm{Rh}$-negative women who were admitted to hospital in Newcastle upon Tyne for therapeutic abortion or for curettage following spontaneous abortion.

\section{Method \\ Samples were collected, where possible, before and after opera- tion for the detection of transplacental haemorrhage with the Kleihauer technique. Rh-antibody tests were performed by the indirect Coombs test and Löw's papain technique as well as by a sensitive enzyme method using papainized cells (Murray and Dewar, 1971). Wherever possible, blood samples were collected before operation for such antibody tests, and an attempt was made to obtain a follow-up sample six months after operation, but we were well aware of the potential difficulties in following a sample of women, many of whom would change address or would not wish to be reminded of the operation. Our maximum effort was concentrated on women in whom this was the first pregnancy, who would provide the most reliable evidence of primary immunization.}

\section{Results}

Of the 177 rhesus-negative women in this series, 83 were pregnant for the first time and $48(58 \%)$ of these were successfully followed-up; 94 had had one or more previous pregnancies and $48(51 \%)$ of these were followed-up. The 81 patients who defaulted and where no postoperative specimen was obtained have been compared with the 96 followed-up, and the two groups differ in only two respects. The proportion of early gestations (12 weeks or less) was higher among the primigravidae who defaulted than among those who were followed up (Table I). Of the 96 patients followed up 10 had an abdominal hysterotomy 
TABLE I-Length of Gestation in 177 Rh-Negative Women in whom Follow-up was Attempted

\begin{tabular}{|c|c|c|c|c|c|c|c|c|}
\hline \multirow{2}{*}{\multicolumn{3}{|c|}{$\begin{array}{l}\text { Length of } \\
\text { Gestation } \\
\text { (weeks) }\end{array}$}} & \multicolumn{2}{|c|}{ Primigravidae } & \multicolumn{2}{|c|}{ Multigravidae } & \multicolumn{2}{|c|}{ All Parities } \\
\hline & & & Tested & Defaulted & Tested & Defaulted & Tested & Defaulted \\
\hline $\begin{array}{l}\text { Up to } 12 \text { weeks } \\
13 \text { weeks }+\ldots \\
\text { Not known } \ldots\end{array}$ & $\begin{array}{l}\ldots \\
\cdots \\
\cdots\end{array}$ & $\begin{array}{l}\cdots \\
\cdots \\
\cdots\end{array}$ & $\begin{array}{l}19(39 \cdot 6) \\
18(37 \cdot 5) \\
11(22 \cdot 9)\end{array}$ & $\begin{array}{r}22(62.9) \\
9(25 \cdot 7) \\
4(11.4)\end{array}$ & $\begin{array}{c}25(52 \cdot 1) \\
22(45 \cdot 8) \\
1(2 \cdot 1)\end{array}$ & $\begin{array}{r}23(50 \cdot 0) \\
22(47 \cdot 8) \\
1(2 \cdot 2)\end{array}$ & $\begin{array}{l}44(45 \cdot 8) \\
40(41 \cdot 7) \\
12(12 \cdot 5)\end{array}$ & $\begin{array}{r}45(55 \cdot 5) \\
31(38 \cdot 3) \\
5(6 \cdot 2)\end{array}$ \\
\hline Total & . & . & $48(100)$ & $35(100)$ & $48(100)$ & $46(100)$ & $96(100)$ & $81(100)$ \\
\hline
\end{tabular}

while of the 81 defaulters 17 had this operation. We do not believe that either of these differences affects the interpretation of our results.

A total of 146 patients were examined for evidence of trans-

TABLE II-Incidence of Transplacental Haemorrhage According to Length of Gestation in 146 Cases Submitted to a Kleihauer Test

\begin{tabular}{|c|c|c|c|c|c|}
\hline \multirow{2}{*}{\multicolumn{3}{|c|}{$\begin{array}{l}\text { Estimated Quantity } \\
\text { of Fetal Blood }\end{array}$}} & \multicolumn{3}{|c|}{ Whether or Not Followed for Antibodies } \\
\hline & & & Followed Up & Defaulted & Total \\
\hline \multirow[t]{2}{*}{$\begin{array}{l}\text { None } \\
<0.1 \mathrm{ml} . \\
0.1 \mathrm{ml}+\end{array}$} & $\begin{array}{l}. \\
\therefore\end{array}$ & $\begin{array}{l}\ldots \\
\cdots\end{array}$ & $\begin{array}{r}51(71.8) \\
13(18.3) \\
7(9.9)\end{array}$ & $\begin{array}{r}53(70 \cdot 7) \\
20(26 \cdot 7) \\
2(2 \cdot 7)\end{array}$ & $\begin{array}{r}104(71 \cdot 2) \\
33(22 \cdot 6) \\
9(6 \cdot 2)\end{array}$ \\
\hline & & & $71(100)$ & $75(100)$ & $146(100)$ \\
\hline
\end{tabular}

TABLE III-Incidence of Rhesus Isoimmunization Related to Amount of Transplacental Haemorrhage in 96 Cases Followed up

\begin{tabular}{|c|c|c|c|c|c|c|}
\hline \multirow{2}{*}{$\begin{array}{l}\text { Amount of Fetal } \\
\text { Bleeding }\end{array}$} & \multicolumn{2}{|c|}{ Primigravidae } & \multicolumn{2}{|c|}{ Multigravidae } & \multicolumn{2}{|c|}{ Total } \\
\hline & No. & Antibodies & No. & Antibodies & No. & Antibodies \\
\hline $\begin{array}{l}\text { None } \ldots \\
<0 \cdot 1 \mathrm{ml} \ldots \\
0 \cdot 1 \mathrm{ml}+ \\
\text { No Kleihauer test }\end{array}$ & $\begin{array}{r}19 \\
7 \\
3 \\
19\end{array}$ & $\begin{array}{lc}1 & (5 \cdot 3) \\
1 & (14 \cdot 3) \\
0 & \\
1 & (5 \cdot 3)\end{array}$ & $\begin{array}{r}32 \\
6 \\
4 \\
6\end{array}$ & $\begin{array}{l}5(15 \cdot 6) \\
0 \\
1(25 \cdot 0) \\
0\end{array}$ & $\begin{array}{r}51 \\
13 \\
7 \\
25\end{array}$ & $\begin{array}{l}6(11 \cdot 8) \\
1 \quad(7 \cdot 7) \\
1(14 \cdot 3) \\
1 \quad(4 \cdot 0)\end{array}$ \\
\hline Total & 48 & $3(6 \cdot 3)$ & 48 & $6(12 \cdot 5)$ & 96 & $9(9 \cdot 4)$ \\
\hline
\end{tabular}

Percentage immunized is given in parentheses placental haemorrhage (Table II) and nine had the equivalent of $0.1 \mathrm{ml}$ or more of fetal blood. Only 71 out of the 96 patients successfully followed-up had a Kleihauer test and 51 had no demonstrable transplacental haemorrhage. This proportion $(72 \%)$ is the same as in the group who defaulted $(71 \%)$.

Out of 96 patients successfully followed-up, 86 had been tested before operation and found to be free of antibodies. Anti$\mathrm{D}$ antibodies were found in three primigravidae and in six multigravidae, and details of these cases are shown in Table III. Most were examined between six and nine months after abortion but because of difficulty in tracing some patients a few were later than this, the longest interval between operation and testing being 14 months. The incidence of antibodies was not related to the length of gestation, being 4 out of 44 for those 12 weeks or less and 4 out of 40 for those 13 or more weeks pregnant. The mode of abortion is shown in Table IV which indicates that three cases were associated with the use of intraamniotic saline, an incidence higher than that associated with other methods of termination. The numbers are, however, too small for this difference to be of statistical significance.

In only two patients was the antibody found by the indirect Coombs test, in the remaining seven antibodies could be detected only with enzyme-treated cells (Table V). In addition to the 177 patients described above another 16 were known to have $\mathrm{Rh}$-antibodies before the abortion; 15 were detectable by indirect Coombs test, but one is of particular interest:

TABLE IV-Incidence of Postoperative Immunization (In Those Patients Followed Up) According to the Method of Abortion

\begin{tabular}{|c|c|c|c|c|c|c|c|c|c|}
\hline & & & \multicolumn{7}{|c|}{ Number of Previous Pregnancies } \\
\hline \multirow{2}{*}{\multicolumn{3}{|c|}{ Method of Termination }} & \multicolumn{2}{|c|}{ None } & \multicolumn{2}{|c|}{ One or More } & \multicolumn{3}{|c|}{ Total } \\
\hline & & & No. of Cases & $\begin{array}{l}\text { No. with } \\
\text { Antibodies }\end{array}$ & No. of Cases & $\begin{array}{l}\text { No. with } \\
\text { Antibodies }\end{array}$ & No. of Cases & $\begin{array}{l}\text { No. with } \\
\text { Antibodies }\end{array}$ & $\begin{array}{c}\text { Incidence of } \\
\text { Anti-D }\end{array}$ \\
\hline $\begin{array}{lll}\text { Spontaneous } & . \\
\text { Suction curettage } & \ldots \\
\text { Abdominal hysterotomy } & . \\
\text { Intra-amniotic saline } & \ldots \\
\text { Other methods } & \ldots & \ldots \\
\text { Not stated } & \ldots & \ldots\end{array}$ & $\begin{array}{l}\because \\
\because \\
\because \\
\cdots\end{array}$ & $\begin{array}{l}\ldots \\
\because \\
\cdots \\
\cdots\end{array}$ & $\begin{aligned} 7(14 \cdot 6) \\
27(56 \cdot 3) \\
2(4 \cdot 2) \\
10(20 \cdot 7) \\
0 \\
2(4 \cdot 2)\end{aligned}$ & $\begin{array}{l}0 \\
1 \\
0 \\
2 \\
0 \\
0\end{array}$ & $\begin{aligned} 4(8 \cdot 3) \\
27(56 \cdot 2) \\
8(16 \cdot 7) \\
8(16 \cdot 7) \\
1(2 \cdot 1) \\
0\end{aligned}$ & $\begin{array}{l}0 \\
4 \\
1 \\
1 \\
0 \\
0\end{array}$ & $\begin{array}{l}11(11 \cdot 5) \\
54(56 \cdot 1) \\
10(10 \cdot 4) \\
18(18 \cdot 8) \\
1(1 \cdot 0) \\
2(2 \cdot 2)\end{array}$ & $\begin{array}{l}0 \\
5 \\
1 \\
3 \\
0 \\
0\end{array}$ & $\begin{array}{r}9.3 \% \\
10.0 \% \\
16.7 \%\end{array}$ \\
\hline & & & $48(100)$ & 3 & $48(100)$ & 6 & $96(100)$ & 9 & $9 \cdot 4 \%$ \\
\hline
\end{tabular}

Percentages are given in parentheses.

TABLE v-Details of 9 Cases in Whom Antibodies were Detected for the First Time After Operation

\begin{tabular}{|c|c|c|c|c|c|c|c|c|c|c|}
\hline \multirow{3}{*}{ Reference } & \multicolumn{2}{|c|}{$\begin{array}{l}\text { Previous } \\
\text { Pregnancy }\end{array}$} & \multirow{3}{*}{$\begin{array}{l}\text { Length of } \\
\text { Gestation } \\
\text { (weeks) }\end{array}$} & \multirow{3}{*}{$\begin{array}{c}\text { Type of } \\
\text { Abortion }\end{array}$} & \multirow{3}{*}{$\begin{array}{l}\text { Maximum } \\
\text { Fetal Count } \\
\text { (Fetal/Adult } \\
\text { cells) }\end{array}$} & \multicolumn{5}{|c|}{ Antibody Tests } \\
\hline & Viable & & & & & \multirow{2}{*}{ Preoperative } & \multicolumn{4}{|c|}{ Postoperative } \\
\hline & Viavic & viable & & & & & $\begin{array}{c}\text { Gestation } \\
\text { weeks }\end{array}$ & I.C.T. & $\begin{array}{l}\text { Low's } \\
\text { Papain }\end{array}$ & $\begin{array}{l}\text { Papainized } \\
\text { Cells }\end{array}$ \\
\hline $\begin{array}{r}\text { LB } \\
4400 \\
4409 \\
4246 \\
4441 \\
4343 \\
4083 \\
4395 \\
2013\end{array}$ & $\begin{array}{l}0 \\
0 \\
0 \\
0 \\
3 \\
1 \\
3 \\
3 \\
1 \\
1\end{array}$ & $\begin{array}{l}0 \\
0 \\
0 \\
0 \\
0 \\
1 \\
0 \\
0 \\
0\end{array}$ & $\begin{array}{l}\text { N.K. } \\
16 \\
14 \\
18 \\
13 \\
12 \\
12 \\
11 \\
10\end{array}$ & $\begin{array}{l}\text { Suction curettage } \\
\text { I.A. Saline } \\
\text { I.A. Saline } \\
\text { Hysterotomy } \\
\text { I.A. Saline } \\
\text { Suction curettage } \\
\text { Suction curettage } \\
\text { Suction curettage } \\
\text { Suction curettage }\end{array}$ & $\begin{array}{c}0 \\
\text { N.T. } \\
1 / 202,000 \\
0 \\
0 \\
0 \\
0 \\
1 / 23,750 \\
0\end{array}$ & $\begin{array}{l}\text { Nil } \\
\text { Nil } \\
\text { Nil } \\
\text { Nil } \\
\text { Nil } \\
\text { Nil } \\
\text { Nil } \\
\text { Nil. } \\
\text { N.T. }\end{array}$ & $\begin{array}{r}5 \\
7 \\
12 \\
6 \\
6 \\
7 \\
8 \\
7 \\
7\end{array}$ & $\begin{array}{l}+ \\
0 \\
0 \\
0 \\
0 \\
0 \\
+ \\
0 \\
0\end{array}$ & $\begin{array}{l}++ \\
0 \\
++ \\
0 \\
0 \\
0 \\
++ \\
++ \\
+\end{array}$ & $\begin{array}{r}+++ \\
+ \\
++ \\
++ \\
+ \\
+ \\
\text { N.T. } \\
++ \\
+++\end{array}$ \\
\hline
\end{tabular}

* Known to be free of antibodies after last delivery in 1964

I.C.T. = Indirect Coombs test. N.T. = Not tested. 
A primigravida aged 18 had a termination of pregnancy by suction curettage at 11 weeks. The preoperation blood sample was found to contain specific anti-D detected by Löw's papain technique only, and not by the use of papainized cells. A history of concealed pregnancy or of previous blood transfusions has been carefully excluded, and the laboratory findings have been repeatedly checked on the original specimen and in specimens obtained since operation. The antibody appears to be a non-immune type of anti-D evident only after the serum had been "activated" with papain.

\section{Discussion}

There is no dispute over the two patients in whom antibodies were found by the indirect Coombs test and these represent an incidence of isoimmunization after abortion of $2^{\circ}$, similar to that suggested by Freda et al. (1970). The significance of anti-D detected only by enzyme techniques is, however, still a matter of dispute. Some evidence showing that active 'enzyme' $\mathrm{Rh}$ antibodies are of ominous significance for future pregnancies has been presented (Murray, 1971) and we consider that the antibodies to papainized cells reported here after abortion should be taken seriously. Such antibodies probably precede overt immunization, but only experience in following these patients through a subsequent pregnancy will prove whether such antibodies, like those following term pregnancy, will cause haemolytic disease of the newborn.

Including the "enzyme" $\mathrm{Rh}$ antibodies, we report in this series an incidence of primary $\mathrm{Rh}$ immunization of $9.4 \%$, and because of this evidence we now recommend that Rh-negative women not already immunized should be eligible for prophylaxis with anti-D immunoglobulin. The current dose administered for the prevention of $\mathrm{Rh}$ isoimmunization $(200 \mu \mathrm{g})$ is greater than necessary for the size of transplacental haemorrhage likely to occur after abortion.

Transplacental haemorrhage, as detected by the Kleihauer test, was found in only $29 \%$ of patients in this series and, as can be seen in Table III, seemed to be of no value in predicting the development of anti-D. At best, this assessment of transpla- cental haemorrhage is an inexact measurement and we think that there is no justification for using the time-consuming Kleihauer test as a screening procedure in all cases of abortion eligible for prophylaxis. Only nine cases had a transplacental haemorrhage of $0.1 \mathrm{ml}$ or more of fetal blood. The largest transplacental haemorrhage we recorded in either this or our previous series (Murray et al., 1970) was one of $2.9 \mathrm{ml}$ of fetal blood in a patient terminated at 16 weeks by intra-amniotic saline. The dose of immunoglobulin required to protect against $1 \mathrm{ml}$ of fetal blood has been estimated to be under $75 \mu \mathrm{g}$ (Mollison et al., 1969) and less than this might be an appropriate dose for cases of abortion.

We have already referred to the practical difficulties of testing and following up women subjected to therapeutic abortion, and some safeguard will be necessary to ensure that anti-D immunoglobulin is given only to women who are $\mathrm{Rh}$-negative without antibodies. Results of such a prevention programme may prove extremely difficult to assess.

Dr. J. C. M. Smith, our research assistant, undertook the hard work of following up these patients, and we are grateful to the medical and nursing staff of the Newcastle hospitals who so willingly co-operated with us in this study. We gratefully acknowledge the technical help of the staff of the Regional Transfusion Centre and the clerical assistance of Mrs. M. Jackson. This work was carried out with the aid of a research grant given jointly by the United Newcastle Hospitals and the Newcastle Regional Hospital Board.

\section{References}

Freda, V. J., Gorman, J. G., Balen, R. S., and Treacy, N. (1970). Lancet, 2,147 .

Mollison, P. L., Hughes-Jones, M. C., Lindsay, M., and Wessely, J. (1969). Vox Sanguinis, 16, 421 .

Murray, S. (1971). Vox Sanguinis. In press.

Murray, S., Barron, S. L., and McNay, R. A. (1970). Lancet, 1, 631.

Murray, S., and Dewar, P. J. (1971). Transfusion. In press.

\section{MEDICAL MEMORANDA}

\section{Vitamin A for Night-blindness in Prolonged Jaundice}

\author{
JEAN M. WRIGHT, J. S. WRIGHT
}

British Medical fournal, 1971, 3, 92-93

Though still a leading cause of blindness in many parts of the world, dietary deficiency of vitamin $A$ is rarely encountered in Britain. Sherlock (1968) mentioned failure of dark-adaptation

\section{Walton, Liverpool, L9 1AZ}

JEAN M. WRIGHT, M.B., D.oBst.R.c.o.G., General Practitioner

Sefton General Hospital, Liverpool 15

J. S. WRIGHT, M.B., M.R.C.P., Senior Registrar as a possible consequence of the malabsorption resulting from prolonged cholestasis, but we have been unable to find any reports of night blindness as a result of prolonged biliary obstruction. We therefore feel prompted to report this complication since this at least of the many distressing symptoms of prolonged obstructive jaundice is very readily treated.

\section{Case Report}

The patient, a man aged 67, presented with jaundice in May 1969. After initial fluctuation the pattern became clearly obstructive, with heavy biliuria and bulky acholic stools. Laparotomy on 24 June showed an adenocarcinoma involving the cystic and common bile ducts and extending up into the portal fissure in such a way that neither resection nor bypass procedure could be carried out. Deterioration was slow, with anorexia, pruritus, and gradually deepening jaundice over the year following laparotomy.

In July 1970 he first complained of visual symptoms. In the half-light of the evening he found increasing difficulty in distinguishing objects in his room. If he rose from his bed at night he found he was completely blind, whereas light from the street would previously have been sufficient to allow him to move about the room. When the lighting was good his vision was satisfactory, with the exception that he was unable to read newsprint. He was deeply jaundiced at this stage and emaciated, with a dry scaly skin. The 